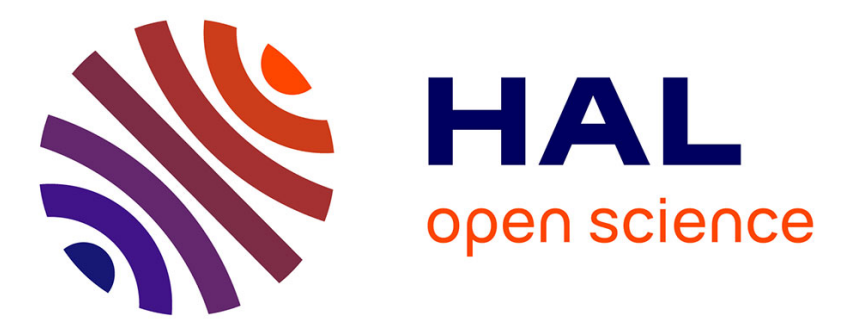

\title{
Antimicrobial, antitumor and side effects assessment of a newly synthesized tamoxifen analogue
}

Fatma Abdmouleh, Mehdi El Arbi, Hajer Ben Saad, Karim Jellali, Emna E.

Ketata, Ibtissem Ben Amara, Pascal Pigeon, Hanen Ben Hassen, Siden Top, Gérard Jaouen, et al.

\section{To cite this version:}

Fatma Abdmouleh, Mehdi El Arbi, Hajer Ben Saad, Karim Jellali, Emna E. Ketata, et al.. Antimicrobial, antitumor and side effects assessment of a newly synthesized tamoxifen analogue. Current Topics in Medicinal Chemistry, 2020, 20 (25), pp.2281-2288. 10.2174/1568026620666200819145526. hal-02921197

\section{HAL Id: hal-02921197 \\ https://hal.science/hal-02921197}

Submitted on 2 Sep 2020

HAL is a multi-disciplinary open access archive for the deposit and dissemination of scientific research documents, whether they are published or not. The documents may come from teaching and research institutions in France or abroad, or from public or private research centers.
L'archive ouverte pluridisciplinaire HAL, est destinée au dépôt et à la diffusion de documents scientifiques de niveau recherche, publiés ou non, émanant des établissements d'enseignement et de recherche français ou étrangers, des laboratoires publics ou privés. 


\section{Antimicrobial, antitumor and side effects assessment of a newly}

4 Fatma Abdmouleh $^{1 \star}$, Mehdi El Arbi ${ }^{1,2^{*}}$, Hajer Ben Saad $^{3 \star}$, Karim Jellali ${ }^{1 \star}$, Emna Ketata ${ }^{1}$,

5 Ibtissem Ben Amara ${ }^{2}$, Pascal Pigeon ${ }^{4,5}$, Hanen Ben Hassen ${ }^{2}$, Siden Top ${ }^{4}$, Gérard Jaouen ${ }^{4,5}$,

6 Riadh Hammami ${ }^{6, *}$, Mamdouh Ben $\mathrm{Ali}^{1}$, Girish Kumar Gupta ${ }^{7}$

7

$8{ }^{1}$ Centre of Biotechnology of Sfax, University of Sfax, Route de Sidi Mansour km 6, 3018 9 Sfax, Tunisia

10 Institut Supérieur de Biotechnologie de Sfax, Université de Sfax, Route de Sokra km 4, 3000

11 Sfax, Tunisia

$12{ }^{3}$ Faculty of Medicine, University of Sfax, Laboratory of Pharmacology UR/12 ES-13, 3029

13 Sfax, Tunisia

$14{ }^{4}$ Sorbonne Université, UMR 8232 CNRS, IPCM, 4 place Jussieu, F-75005 Paris (France)

$15{ }^{5}$ PSL, Chimie ParisTech, 11 rue Pierre et Marie Curie, F-75005 Paris (France)

$16{ }^{6}$ School of Nutrition Sciences, University of Ottawa, Ottawa, K1N 7 K4, ON, Canada

$17{ }^{7}$ Department of Pharmaceutical Chemistry, Sri Sai College of Pharmacy, Badhani, Pathankot18 145001, Punjab, India

$19{ }^{*}$ Corresponding author: mehdi.elarbi@isbs.usf.tnor rhammami@uottawa.ca

$20{ }^{\star}$ These authors contributed equally to the realization of this work

\section{Abstract}

Tamoxifen citrate is a very prevalent drug marketed under several trade names like ApoTamox, Nolvadex, Tamec, Tamizam and Tamoplex. This molecule is approved by the FDA for breast cancer treatment. Some studies have shown that tamoxifen has anti-tuberculosis and anti-parasitic activities. Like any drug tamoxifen possesses side effects, more or less dangerous. Basically, this work is a comparative study which aims to: Primarily compare the 
27 antimicrobial and antitumor activities of tamoxifen and a newly synthesized tamoxifen 28 analogue. Secondly, determine the molecule with lesser side effects. Three groups of mice 29 were injected with tamoxifen citrate and compound 2 (1,1-bis[4-(330 dimethylaminopropoxy)phenyl]-2-phenyl-but-1-ene dihydrochloride) at doses corresponding 31 to $\mathrm{C} 1(1 / 10), \mathrm{C} 2(1 / 50), \mathrm{C} 3(1 / 100)$ to compound 2 lethal dose $\left(\mathrm{LD}_{50}=75 \mathrm{mg} / \mathrm{kg}\right)$ 32 administered for adult mice. A group of not injected mice has served as a study control. 33 Experimental results suggest that compound 2 have better antitumor and antimicrobial 34 activity than tamoxifen citrate besides its lower toxicity effects.

35 Keywords: tamoxifen citrate, 1,1-bis[4-(3-dimethylaminopropoxy)phenyl]-2-phenyl-but-136 ene dihydrochloride, antimicrobial activity, antitumor, toxicity, mice. 


\section{Introduction}

Nowadays humans are exposed to a variety of diseases, with a degree of dangerousness and virulence that continues to grow each year. This effect can be detected by the emergence of diseases that are resistant to treatments previously discovered and approved by agencies such as the Food and Drug Administration (FDA). This resistance is underlined in the cases of infectious diseases, cancer and several other diseases. Bacteria[1, 2], viruses[3] and malignant cancer cells adapt to therapies and find ways to escape the treatment $[4,5]$.

Many organizations like United Nations (UN) and WHO sounded the alarm on the inefficiency of older treatments against new emerging bacterial strains, which can be catastrophic because it can lead to a human powerlessness against a possible outbreak if emergency measures are not taken, like the discoveries of new active molecules and new treatments to combat multidrug-resistant strains[6].

For this purpose, research laboratories and pharmaceutical companies have focused on this subject. Several research strategies have been developed to search for effective products: natural way, by analysis of plant extracts, or synthetic way. In this paper, we will focus about chemically synthesized molecule $[7,8]$.

Tamoxifen (ICI46,474) is an example of "magical" molecule, with a very remarkable story. Essentially synthesized by Imperial Chemical Industries ICI (AstraZeneca) as part of a fertility control program, this selective estrogen receptor modulator has failed on the goal in which it was designed. After the establishment of links between estrogen and hormone dependent breast cancer in 1960, tamoxifen has been clinically tested for breast cancer disease where it has shown encouraging results[9]. 
In 1973, tamoxifen has been marketed in the UK as a breast cancer treatment and in 1975 as an ovulation inductor. The FDA approved tamoxifen as treatment of metastatic breast cancer in $1977[10]$.

Thereafter, in 1986 it was approved as adjuvant together with chemotherapy. Later between 1988 and 1990 it was recognized and allowed to be used alone for patients with: nodepositive post-menopausal and pre or post-menopausal node-negative estrogen positive disease. In the same period, tamoxifen was approved as a risk reducer for high-risk women for breast cancer. Three years after, men with breast cancer was treated with it (1993). In 2000, tamoxifen treatment in situ of ductal carcinoma (DCIS) was approved[11].

Like any drug tamoxifen has side effects, more or less dangerous. The percentage of occurrence, frequency and the manifestation of these effects are variable, and depend mostly on two factors: the dose administered and the subject receiving the treatment. According to the guide of use and labels approved by FDA for tamoxifen commercialization and some others studies, with tamoxifen the incidence of uterine malignancies (uterus-endometrial cancer and uterine sarcoma) is increased by $50 \%[12,13]$. Tamoxifen also causes gynecologic symptoms like pelvic pain, menstrual irregularities, and vaginal bleeding[14]. The thrombo embolic events were reported (pulmonary embolism and deep vein thrombosis) [15]. Liver can be affected with tamoxifen and some severe hepatic abnormalities including fatty changes in the liver, cholestasis, hepatitis, hepatic necrosis (some fatal) and liver cancer were reported [12]. Hypercalcemia, visual disturbance, nausea, depression in addition of abnormality in hematology and lipid profiles are mentioned [12].

Recent innovative studies have shown that tamoxifen has activity against bacteria even those that present a problem of resistance such as tuberculosis; In addition to the activity against leishmaniosis that has been indicated $[16,17]$. 
Ferrocenyl or phenyl derivatives of diphenyl butene series, that are tamoxifen analogs, are known for their anti-proliferative activity on breast cancer cells and leukemia, as well as for their excellent antimicrobial activity against Escherichia coli, Pseudomonas aeruginosa, Staphylococcus aureus, Enterococcus hirae, P. savastanoi pv. Savastanoi, A. tumefaciens, F. Solani, Listeria monocytogenes and Salmonella enterica [18-24].

The focus of this study is based on the comparison of two molecules: tamoxifen citrate and newly synthesized Compound 2. This comparison is made on two parts: a microbiological aspect corresponding to the test of the activities of these two molecules against Gramnegative and Gram-positive bacteria as first part, and the evaluation of toxicological effects on mice as second part. Compound $\mathbf{2}$ is the dihydrochloride version of compound $\mathbf{1}$ and was used in place of $\mathbf{1}$ in order to make it soluble into water.

\section{Materials and methods}

\subsection{Chemical compounds}

Tamoxifen citrate was purchased from Sigma Chemical Company (Dorset, UK). 1,1-bis[4-(3dimethylaminopropoxy)phenyl]-2-phenyl-but-1-ene dichloride(compound 2) was prepared (Figure 1). Compound 1 [25] (1.15 g, $2.36 \mathrm{mmol})$ was dissolved in $150 \mathrm{~mL}$ of diethyl ether and stirred. A $2 \mathrm{M}$ solution of hydrochloric acid in diethyl ether $(2.6 \mathrm{~mL}, 5.2 \mathrm{mmol})$ was added drop-wise into the solution. A white precipitate was immediately formed. After stirring for $20 \mathrm{~min}$, the mixture was filtered under argon and the obtained white solid was washed with $3 \times 5 \mathrm{~mL}$ of diethyl ether and dried under vacuum, giving compound 2 in quantitative yield. Crystals contain traces of diethyl ether that can't be removed even after several hours under high vacuum, making elemental analysis not relevant. ${ }^{1} \mathrm{H}$ NMR (DMSO-d 6 ): $\delta 0.88(\mathrm{t}, J$ $\left.=7.1 \mathrm{~Hz}, 3 \mathrm{H}, \mathrm{CH}_{3}\right), 2.03-2.30\left(\mathrm{~m}, 4 \mathrm{H}, \mathrm{CH}_{2}\right), 2.37-2.50\left(\mathrm{~m}, 2 \mathrm{H}, \mathrm{CH}_{2}\right), 2.75(\mathrm{~d}, J=4.4 \mathrm{~Hz}$, 
$\left.6 \mathrm{H}, \mathrm{NMe}_{2}\right), 2.80\left(\mathrm{~d}, J=4.4 \mathrm{~Hz}, 6 \mathrm{H}, \mathrm{NMe}_{2}\right), 3.09-3.32\left(\mathrm{~m}, 4 \mathrm{H}, \mathrm{CH}_{2} \mathrm{~N}\right), 3.94(\mathrm{~d}, J=5.1 \mathrm{~Hz}$, $\left.2 \mathrm{H}, \mathrm{CH}_{2} \mathrm{O}\right), 4.11\left(\mathrm{~d}, J=5.1 \mathrm{~Hz}, 2 \mathrm{H}, \mathrm{CH}_{2} \mathrm{O}\right), 6.63\left(\mathrm{~d}, J=8.4 \mathrm{~Hz}, 2 \mathrm{H}, \mathrm{C}_{6} \mathrm{H}_{4}\right), 6.76(\mathrm{~d}, J=8.4$ $\left.\mathrm{Hz}, 2 \mathrm{H}, \mathrm{C}_{6} \mathrm{H}_{4}\right), 6.98\left(\mathrm{~d}, J=8.4 \mathrm{~Hz}, 2 \mathrm{H}, \mathrm{C}_{6} \mathrm{H}_{4}\right), 7.07-7.29\left(\mathrm{~m}, 7 \mathrm{H}, \mathrm{C}_{6} \mathrm{H}_{4}+\mathrm{C}_{6} \mathrm{H}_{5}\right), 10.84-11.22$ $\left(\mathrm{m}, 2 \mathrm{H}, \mathrm{NH}^{+}\right) .{ }^{13} \mathrm{C} \mathrm{NMR}\left(\mathrm{DMSO}_{6}\right): \delta 14.3\left(\mathrm{CH}_{3}\right), 24.7\left(\mathrm{CH}_{2}\right), 24.8\left(\mathrm{CH}_{2}\right), 29.5\left(\mathrm{CH}_{2}\right), 42.8$ $\left(\mathrm{NMe}_{2}\right), 42.9\left(\mathrm{NMe}_{2}\right), 54.8\left(\mathrm{CH}_{2} \mathrm{~N}\right), 54.9\left(\mathrm{CH}_{2} \mathrm{~N}\right), 65.6\left(\mathrm{CH}_{2} \mathrm{O}\right), 65.8\left(\mathrm{CH}_{2} \mathrm{O}\right), 114.3(2 \mathrm{CH}$ $\left.\mathrm{C}_{6} \mathrm{H}_{4}\right), 115.1\left(2 \mathrm{CHC}_{6} \mathrm{H}_{4}\right), 127.0\left(\mathrm{CHC}_{6} \mathrm{H}_{5}\right), 128.9\left(2 \mathrm{CH}_{\text {arom }}\right), 130.3\left(2 \mathrm{CH}_{\text {arom }}\right), 131.1$ (2 $\left.\mathrm{CH}_{\text {arom }}\right), 132.4$ (2 $\left.\mathrm{CH}_{\text {arom }}\right), 136.4(\mathrm{C}), 136.7$ (C), 138.4 (C), 141.4 (C), 142.9 (C), 157.1 (C), 157.9 (C). IR (KBr, v cm $\left.{ }^{-1}\right): 3026,2961,2688,2512,2474\left(\mathrm{CH}, \mathrm{CH}_{2}, \mathrm{CH}_{3}\right)$.

\subsection{Bacterial strains and growth conditions}

Listeria monocytogenes ATCC 7644, Staphylococcus aureus ATCC 6538, Escherichia coli ATCC 10536, Escherichia coli K12ATCC 23716 were used as indicator strains. Bacteria were grown aerobically in LB broth (Difco laboratories, Sparks, MD, USA) at $30^{\circ} \mathrm{C}$ for $24 \mathrm{~h}$.

\subsection{Determination of the antimicrobial activity}

Micro dilution method on 96 well plates was used to estimate the antimicrobial effects of molecules. Tamoxifen citrate and compound 2, were dissolved in double-distilled sterile water, the levofloxacin was dissolved in dimethyl sulfoxide (DMSO). A serial of two half dilutions were performed for each molecule to be tested in a final volume of $100 \mu \mathrm{L}$ and every well was inoculated with $100 \mu \mathrm{L}$ bacterial culture $\left(10^{6} \mathrm{CFU} / \mathrm{mL}\right)$. The final concentrations of each molecule were $100 \mu \mathrm{g} / \mathrm{mL}, 50 \mu \mathrm{g} / \mathrm{mL}, 25 \mu \mathrm{g} / \mathrm{mL}, 12.5 \mu \mathrm{g} / \mathrm{mL}, 6.25 \mu \mathrm{g} / \mathrm{mL}, 3.1 \mu \mathrm{g} / \mathrm{mL}$, $1.55 \mu \mathrm{g} / \mathrm{mL}$ and $0.75 \mu \mathrm{g} / \mathrm{mL}$. A set of wells containing $200 \mu 1$ of LB medium was used as negative control and a blank for reading the optical density at $600 \mathrm{~nm}$. The positive control contained $100 \mu \mathrm{L}$ of $\mathrm{LB}$ medium inoculated with $100 \mu$ Lof culture $\left(10^{6} \mathrm{CFU} / \mathrm{mL}\right)$ obtained after overnight culture of $16 \mathrm{~h}$ shaking at $30{ }^{\circ} \mathrm{C}$. The MIC (Minimal Inhibitory Concentration) was determined as the minimal concentration of molecule where no visible growth was noted. 
137 MTT, (3-(4,5dimethythiazol-2-yl)-2,5-diphenyl tetrazolium bromide), was used to determine

138 the MIC. A sample from each well was plated on solid LB medium and maintained overnight

139 at $30^{\circ} \mathrm{C}$ to determine the $\mathrm{MBC}$ as the lowest concentration of molecule corresponding to the

140 inhibition of $95 \%$ of cells growth. The IA was calculated according to the formula:

$$
I A(\%)=100 *\left\langle 1-\frac{[O D 600(M)-O D 600(i)]}{[O D 600(C)-O D 600(i)]}\right\rangle
$$

141 Where $\mathrm{M}$ is OD with molecule and $\mathrm{C}$ is OD of control culture.

142

143

144

145

146

147

148

149

150

151

152

153

154

155

\subsection{Cell viability assay}

MCF7 cells ( $5 \times 10^{4}$ ) were seeded in 98 -well plates and left to grow overnight. The following day, cells were treated with increasing concentrations of Tamoxifen citrate and compound 2 $(0.1 \mu \mathrm{M}$ to $1 \mathrm{mM})$ in triplicate. After $24 \mathrm{~h}$, cell viability was measured using the Cell Proliferation kit (MTT). Results were representative of at least three independent experiments, and were expressed as inhibition rate in reference to the cell growth without drug treatment.

\subsection{Animals}

Three-to-five-week-old swiss mice $(\approx 20 \mathrm{~g})$ were purchased from Central Pharmacy (SIPHAT, Tunisia), quarantined for more than 1 week before starting the experiments, kept under pathogen-free conditions, and handled according to the Guidelines of the "Institute Ethical Committee Guidelines"for the care and use of laboratory animals [26], as provided by the Ethical Committee of Facultyof Sciences at University of Sfax, which approved the present animal experiments. 


\subsection{Experimental design}

157 Mice were accommodated in polycarbonate cages and were daily provided with water and

158 standard pellet diet (SNA, Sfax, Tunisia). Cages are kept in an air-conditioned room, 159 temperature $22 \pm 3{ }^{\circ} \mathrm{C}$ and $40 \%$ of relative humidity. After intraperitoneal injection, the lethal 160 dose of compound 2 and tamoxifen citrate resulting in $50 \%$ mortality $\left(\mathrm{LD}_{50}\right)$ were found as $16175 \mathrm{mg} / \mathrm{kg}$ and $218 \mathrm{mg} / \mathrm{kg}$ body weight (bw), respectively. In this study, we used the $\mathrm{LD}_{50}$ of compound $2(75 \mathrm{mg} / \mathrm{kg})$ for both molecules in order to compare their effects for the same dose. Mice were divided into seven groups, counting seven mice per each. The first group was used as control groups 2, 3, and 4 were injected by tamoxifen citrate and groups 5,6 , and 7 by compound 2. Tamoxifen citrate and compounds 2 doses $(\mathrm{C} 1=1 / 10, \mathrm{C} 2=1 / 50, \mathrm{C} 3=1 / 100$ of

$166 \mathrm{LD}_{50}$ of compound $2(75 \mathrm{mg} / \mathrm{kg})$ were not lethal to mice. Both molecules were dissolved in water and daily intraperitoneally injected to mice. Food, water intake and body weights of mice were daily registered. All mice were killed by cervical decapitation after 15 days of treatment. Heparinized tubes were used to collect the blood, and after centrifugation for 10 min at $2200 \times g$, plasma samples were collected and stored at $-80{ }^{\circ} \mathrm{C}$ for biochemical analysis.

\subsection{Clinical signs feed intake and body weight measurement}

172 The general health appearance of each mouse was daily monitored using the following score 173 system: 1 (no sign of discomfort); 2 (slightly ruffled fur, active); 3 (ruffled fur and back

174 circumflexed, active); 4 (ruffled fur, back circumflexed, inactive, buprenorphine was

175 administered); 5 (ruffled fur, inactive, hunched posture, and closed or sunken eyes, with or 176 without ocular secretions). Mice were weighed every three days and expressed as average for 177 each group throughout the experiments. 


\subsubsection{Hemogram}

180 Also called CBC (Complete Blood Count), it is an automated way to obtain quickly a set of 181 quantitative data about red blood cell (erythrocytes) parameters, white blood cell (leukocytes) 182 count and platelets, including leukocyte formula. Blood was collected in tubes with heparin, 183 and CBC was determined just after animal sacrifice, this service is assumed by the 184 hematology service of Habib Bourguiba Hospital.

\subsubsection{Biochemical markers in plasma}

Plasma lipid parameters including total cholesterol (TC), triglycerides (TG) and high-density lipoprotein cholesterol (HDL) were determined using commercial kits (\#20111, \#20131 and \#20113) purchased from Biomaghreb (Ariana, Tunisia). The low-density lipoprotein cholesterol (LDL) was determined according to Friedewald equation [27]:

$$
L D L=\frac{T C-(T G-H D L)}{H D L}
$$

\subsection{Statistical analyses}

191 Data are presented as mean values with their standard errors (SEM). Data were subjected to

192 ANOVA using the GLM procedure of SAS (SAS Institute, 2003). The means were compared with LSD test. A probability of $\mathrm{P}<0.05$ was required for statistical significance. Treatments

194 with different letters are significantly different $(\mathrm{p}<0.05)$.

\section{Results and Discussion}

196 In a previous published work, several diaryl-butene analogous and derivatives of tamoxifen

197 were tested against pathogenic Gram-positive and Gram-negative bacteria. The idea came

198 from the fact that other research teams have found that tamoxifen citrate has an inhibitory

199 power as bactericidal against the pathogenic germs. Several diaryl-butene have shown some 
very interesting activities. However, compound $\mathbf{2}$ have not been tested. To urge this query and 201 keen interest about the question that whether compound $\mathbf{2}$ has a potential for tumor and bacterial inhibition? and to compare its activity versus tamoxifen citrate.

203 We evaluated cytotoxicity of compound 2 compared to tamoxifen citrate on MCF7 breast 204 cancer cells. As the compound 2 is an analogue of tamoxifen, those cells seem to be a good choice given their invasive appearance. The results appearing in the figure 2 shown that both of the two molecules have an antiproliferative activity against MCF7 cells, however, we noted significant effects differences that favor the compound 2. Indeed, cell's death caused by this compound compared to tamoxifen citrate is equivalent to twice at the concentration of $10 \mu \mathrm{M}$.

209 Our results showed that in the case of MCF7 cells, based on the $\mathrm{LD}_{50}$ value, compound 2 is 210 five times more toxic than the tamoxifen citrate with respective $\mathrm{LD}_{50} \mathrm{~s}$ of $5 \mu \mathrm{M}$ and $25 \mu \mathrm{M}$.

211 Inhibition test was applied with two types of E. coli as gram-negative, and Staphylococcus 212 aureus, Listeria monocytogenes as gram-positive bacterial strains. The antibiotic levofloxacin was used as a control. The MIC and MBC for the different molecules are shown in the table 1.

214 Compound 2 and tamoxifen citrate show a better potential against gram-positive than against 215 gram-negative. The inhibition profiles obtained for tamoxifen citrate and compound 2 are 216 different, a difference that manifested by a better inhibitory activity for compound $\mathbf{2}$ than for 217 tamoxifen citrate, whether for the Gram-positive or Gram-negative (Figure 3). Compound 2 218 and tamoxifen citrate have a ratio MBC/MIC less than or equal to 4, sign of bacteriostatic and 219 not bactericidal activity. MBC of compound 2 for Staphylococcus aureus is $6.25 \mu \mathrm{g} / \mathrm{mL}$, this 220 value corresponds to the MIC of tamoxifen citrate. These results point out that compound $\mathbf{2}$ is 221 much better and more active than tamoxifen citrate, and also has the potential to be used against gram-positive strains especially against Staphylococcus aureus. 
223 Following 15 days of intraperitoneal injection to the mice with tamoxifen citrate and 224 compound 2, a hematologic study was conducted. The findings obtained shows a disturbance 225 in the blood count for different groups injected with tamoxifen citrate and with compound $\mathbf{2}$, 226 compared to the control groups without being injected as depicted in Figure 4. In the scientific 227 literature tamoxifen citrate, as part of these secondary effects, is described as disruptive of 228 blood parameters. In this context, our work has shown a decline in red blood cell count 229 (Figure4A), and variance statistical study on different doses used for each molecule $230\left(\mathrm{LD}_{50} / 100, \mathrm{LD}_{50} / 10\right)$ showed no significant differences. However, variance becomes 231 significant by comparing each molecule to the control group. Although the two molecules to 232 be tested reduce the number of red blood cells, a phenomenon already described for tamoxifen 233 and its active derivatives like hydroxytamoxifen known as factors causing erythrocyte 234 hemolysis [28,29]. Compound $\mathbf{2}$ shows that having a similar effect of reducing the number of 235 these cells, but with a less acute form (Figure 4A). The mean corpuscular volume (MCV) 236 reflecting the size of red blood cells also showed a fall, a decline that seems not to be 237 statistically significant compared to the control group (Figure 4B). However, comparing the 238 effect of the two molecules on the MVC value, the rates of significance become very strong, 239 with a relative decline less important than compound 2. One of the most relevant and 240 interesting things that was revealed by this study is the difference in effect of the molecules 241 tested on platelets. In contrast to tamoxifen citrate which decreases dramatically the number 242 of platelets in the blood, compound 2 has an opposite effect by a slight increase in platelet 243 count relative to the control (Figure 4D). Detrimental effect of Tamoxifen on blood platelets 244 is already well known [30]. The reason might be explained by the fact that tamoxifen causes 245 mini injury into blood vessel, which explains the appearance of hematomas in some organs 246 such as the liver. Due to their role in cicatrization these thrombosis injuries can occur 247 anywhere in the body (lungs, heart and even the brain). Thrombosis risk increase may lead to 
dangerous consequences, like sudden death. Our results also show a significant drop in the 249 number of leukocytes for tamoxifen citrate (Figure 4C). This important downfall for tamoxifen citrate compared to compound $\mathbf{2}$, can induce a mess and declining reliability of the immune system, making the body vulnerable for attack by pathogens [31].

252 In summary comparison between tamoxifen citrate and compound $\mathbf{2}$ as well as their effects on 253 hematological parameters demonstrates that these two molecules cause anemia, but the 254 severity of the decline is greater for tamoxifen (Figure4A). Compound 2, unlike tamoxifen 255 citrate, does not cause leukopenia and thrombocytopenia (Figure 4C, and 4D). In nut shell, 256 compound 2 found to be far less toxic and better than tamoxifen citrate.

257 The analysis of blood biochemical parameters following tamoxifen citrate and compound 2 258 injections shows majorly changes in triglycerides, High-Density Lipoprotein Cholesterol 259 (HDL) and other cholesterol profiles. Statistical analysis of the dose effect for tamoxifen are 260 not significant, therefore all doses are equivalent (Figure 5). The same thing was observed for 261 the different doses of compound 2 used, except for triglycerides and Low-Density Lipoprotein 262 Cholesterol (LDL) where it seems that the dose is related to the effect of the product (Figure $2635)$.

264 Outcome of the study suggested that the two molecules alter in a clear manner the serum 265 concentration of cholesterol and HDL (Figure 5B, and 5C). However, compound 2 alters the 266 serum concentration of triglycerides less than tamoxifen citrate and does not register a 267 significant difference with the control (Figure 5A). Although this change, the statistical scale 268 seems to be not significant for the two molecules for LDL (Figure 5D). Cholesterol decrease 269 in the blood during tamoxifen citrate treatment is something that is well known [32]. 270 However, the problem for the triglyceride levels in the blood following administration of 271 tamoxifen citrate is controversial. The majority of studies carried out leads to the fact that 
272 blood triglycerides level increases following administration of tamoxifen citrate. This increase

273 is due to inhibition of hepatic enzymes involved in lipid metabolism which increases the rate 274 of cell and serum triglycerides [33].Some studies, like our results, founds that tamoxifen 275 citrate causes a drop in plasma lipids cholesterol, triglycerides, LDL and HDL [34-37].

\section{4. Conclusion}

277 The results emerged from the present study confirmed the antitumor and antimicrobial effect 278 of tamoxifen citrate and its hematological side effects. Compound 2 seems to be more 279 effective than tamoxifen citrate for antitumor and antimicrobial treatment while having less 280 hematological side effects and less disruption of the blood biochemical parameters. These 281 findings encourage us to push further studies for compound $\mathbf{2}$ and test it for other therapeutic 282 usage for which tamoxifen was effective.

\section{Acknowledgments}

284 This work was supported by the Ministry of Higher Education and Scientific Research and 285 Technology of Tunisia and the Agence Nationale de la Recherche of France. The authors 286 thank Dr. Choumous Kallel (hematology department head in the University Hospital Habib 287 Bourguiba Sfax) for his help in hematology essays. 


\section{References}

293 1. Boucher, H.W.; Talbot, G.H.; Bradley, J.S.; Edwards, J.E.; Gilbert, D.; Rice, L.B.; Scheld, M.; Spellberg, B.; Bartlett, J. Bad bugs, no drugs: no ESKAPE! An update from the Infectious Diseases Society of America. Clin. Infect. Dis., 2009, 48(1), 1-12.

2. Fair, R.J.; Tor, Y. Antibiotics and bacterial resistance in the 21 st century. Perspect.

3. von Brunn, A. Editorial overview: Engineering for viral resistance. Curr. Opin. Virol.

4. El-Tanani, M.; Dakir, E-H.; Raynor, B.; Morgan, R. Mechanisms of Nuclear Export in

5. $\quad$ Liu. Y.; Li, Q.; Zhou, L.; Xie, N.; Nice, E.C.; Zhang, H.; Huang, C.; Lei, Y. Cancer

6. Organization WH: Antimicrobial resistance: global report on surveillance: World

7. Lewis, K. Platforms for antibiotic discovery. Nat. Rev. Drug Discovery, 2013, 12(5),

8. America IDSo: The $10 \times$ ' 20 Initiative: pursuing a global commitment to develop 10

9. Maximov, P.Y.; McDaniel, R.E.; Jordan, V.C. Carcinogenesis and Tamoxifen. In: 114.

10. Jordan, V.C. Tamoxifen: a most unlikely pioneering medicine. Nat. Rev. Drug

11. Cohen, M.H.; Hirschfeld, S.; Flamm Honig, S.; Ibrahim, A.; Johnson, J.R.; O'Leary,

12. Zeneca Pharmaceuticals. Nolvadex (tamoxifen citrate) prescribing information.

13. Purvis, J. Dear doctor letter regarding warning information on serious or fatal adverse trioxide, tamoxifen citrate, anastrazole, paclitaxel, bexarotene. Oncologist, 2001, 6(1):4-11. effects among women receiving tamoxifen for risk reduction. Wilmington, DE: AstraZeneca Pharmaceuticals; 2002 May 15.

14. Wood, A.J.; Osborne, C.K. Tamoxifen in the treatment of breast cancer. N. Engl. J. Med., 1998, 339(22), 1609-1618.

15. Fisher, B.; Costantino, J.P.; Wickerham, D.L.; Cecchini, R.S.; Cronin, W.M.; Robidoux, A.; Bevers, T.B.; Kavanah, M.T.; Atkins, J.N.; Margolese, R.G. et al: 
Tamoxifen for the prevention of breast cancer: current status of the National Surgical Adjuvant Breast and Bowel Project P-1 study. J. Natl. Cancer Inst., 2005, 97(22),1652-1662.

16. Jang, W.S.; Kim, S.; Podder, B.; Jyoti, M.A.; Nam, K-W.; Lee, B-E.; Song, H-Y. Anti-Mycobacterial Activity of Tamoxifen Against Drug-Resistant and IntraMacrophage Mycobacterium tuberculosis. J. Microbiol. Biotechnol., 2015, 25(6), 946950.

17. Trinconi, C.T.; Reimão, J.Q.; Coelho, A.C.; Uliana, S.R.B. Efficacy of tamoxifen and miltefosine combined therapy for cutaneous leishmaniasis in the murine model of infection with Leishmania amazonensis. J. Antimicrob. Chemother., 2016, 71(5), 1314-1322.

18. El Arbi, M.; Pigeon, P.; Rkhis, A.C.; Top, S.; Rhouma, A.; Rebai, A.; Jaouen, G.;

19. El Arbi, M.; Pigeon, P.; Top, S.; Rhouma, A.; Aifa, S.; Rebai, A.; Vessières, A.;

20. El Arbi, M.; Théolier, J.; Pigeon, P.; Jellali, K.; Trigui, F.; Top, S.; Aifa, S.; Fliss, I.; Jaouen, G.; Hammami, R. Antibacterial properties and mode of action of new triaryl butane citrate compounds. Eur. J. Med. Chem., 76 (2014) 408-413.

21. El Arbi, M.; Jalléli, K.; Trigui, F.; Pigeon, P.; Görmen, M.; Top, S.; Aifa, S.; Fliss, I.; Jaouen, G.; Hammami, R. Efficacy of a novel ferrocenyl diaryl butene citrate compound as a biocide for preventing health care associated infections. Med. Chem. Commun., 2016, 7(5), 948-954.

22. El Arbi, M.; Ketata, E.; Neifar, A.; Mihoubi, W.; Gupta, G.K.; Pigeon, P.; Top, S.; Gargouri, A.; Jaouen, G. Aryl butenes active against K562 cells and lacking tyrosinase inhibitory activity as new leads in the treatment of leukemia. Mini-Rev. Med. Chem., 2018, 18(15). 1294-1301.

23. Jellali, K.; Pigeon, P.; Trigui, F.; Top, S.; Aifa, S.; Jaouen, G.; El Arbi. M. Effect of the amino chain length and the transformation into citric acid salts of aryldiphenylbutenes and ferrocenyl-diphenylbutenes bearing two dimethylaminoalkyl chains on their antimicrobial activities. SpringerPlus 2, 2013, 508, 1-9.

24. Ketata, E.; Neifar, A.; Mihoubi, W.; Pigeon, P.; Gouzi, H.; Mallet, J.-M.; Top, S.; Gupta, G.K.; Jaouen, G.; Gargouri, A.; El Arbi, M. The inhibition of tyrosinase by some aryl butenes: A desired activity or a side effect to avoid. J. Organomet. Chem., 2017, 848, 133-141.

25. Pigeon, P.; Top, S.; Vessières, A.; Huché, M.; Gormen, M.; El Arbi, M.; Plamont, M.A.; McGlinchey, M. J.; Jaouen, G. A new series of ferrocifen derivatives, bearing two aminoalkyl chains, with strong antiproliferative effects on breast cancer cells. New J. Chem., 2011, 35(10), 2212-2218. 
26. Maryland, R.C. (1996) Guide for the care and use of laboratory animals. Institute of Laboratory Animal Resources Commission on Life Sciences, National Research Council National Academy Press, Washington, DC

27. Friedewald, W.T.; Levy, R.I.; Fredrickson, D.S. Estimation of the concentration of low-density lipoprotein cholesterol in plasma, without use of the preparative ultracentrifuge. Clin. Chem., 1972, 18(6), 499-502.

28. Cruz Silva, M.M.; Madeira, V.M.; Almeida, L.M.; Custódio, J.B. .Hemolysis of human erythrocytes induced by tamoxifen is related to disruption of membrane structure. Biochim. Biophys. Acta, 2000, 1464(1), 49-61.

29. Cruz Silva, M.M.; Madeira, V.M.; Almeida, L.M.; Custódio, J.B. Hydroxytamoxifen interaction with human erythrocyte membrane and induction of permeabilization and subsequent hemolysis. Toxicol. In Vitro., 2001, 15(6), 615-22.

30. Yao, J.C.; Thomakos, N.; McLaughlin, P.; Buchholz, T.A.; Kudelka, A.P. Tamoxifeninduced thrombocytopenia. Am. J. Clin. Oncol., 1999, 22(5), 529-32.

31. Behjati, S.; Frank, M.H. The Effects of Tamoxifen on Immunity. Curr. Med. Chem., 2009; 16(24), 3076-3080.

32. Love, R.R.; Mamby, C.C.; Feyzi, J.M. Tamoxifen-induced decreases in total cholesterol with 2 weeks of treatment. J. Natl. Cancer Inst., 1993, 85(16), 1344-5

33. Hozumi, Y.; Kawano, M.; Hakamata, Y.; Miyata, M.; Jordan, V.C. Tamoxifen Inhibits Lipoprotein Activity: In vivo and in vitro Studies. Horm. Res., 2000, 53, 36-39.

34. Cole, LK..; Jacobs, RL.; Vance, DE. Tamoxifen induces triacylglycerol accumulation in the mouse liver by activation of fatty acid synthesis. Hepatology, 2010, 52(4), $1258-65$.

35. Lin, C.; Chen, L-S.; Kuo, S-J.; Chen, D-R. Adjuvant tamoxifen influences the lipid profile in breast cancer patients. Breast Care, 2014, 9(1), 35-39.

36. Gudbrandsen, O.A.; Rost, T.H.; Berge, R.K. Causes and prevention of tamoxifeninduced accumulation of triacylglycerol in rat liver. J. Lipid Res., 2006, 47, 22232232.

37. Reckless, J.; Metcalfe, J.C.; Grainger, D.J. Tamoxifen decreases cholesterol sevenfold and abolishes lipid lesion development in apolipoprotein $\mathrm{E}$ knockout mice. Circulation, 1997, 95, 1542-1548. 
$401 \quad$ Figure legends

402 Figure 1.Preparation of compound $\mathbf{2}$ and structures of the compounds object of the study

403 Figure2. Inhibition of MCF7cells in presence of tamoxifen citrate or compound 2.

404 Figure 3. Growth inhibition of Listeria monocytogenesATCC 7644 (A) and Escherichia coli

405 K12 ATCC 23716 (B) in presence of tamoxifen citrate (square) or compound 2 (triangle).

406 Non-linear regression equation: $\mathrm{Y}=\mathrm{Bottom}+($ Top-Bottom $) /\left(1+10^{\wedge}\left(\left(\operatorname{LogEC} \mathrm{C}_{50^{-}}\right.\right.\right.$

$407 \quad \mathrm{X}) *$ HillSlope)).

408 Figure 4. Effect of tamoxifen citrate and compound 2 at (A) Erythrocytes enumeration; (B)

409 VCM; (C) Leucocytes enumeration and (D) platelets.

410 Figure 5. Effect of tamoxifen citrate and compound 2 on (A) TG; (B) Cholesterol; (C) HDL 411 and (D) LDL profile in blood. 
414 Table 1: Determination of MIC and MBC of Levofloxacin, tamoxifen citrate and compound 2

\begin{tabular}{lcccccc}
\hline \multirow{2}{*}{\multicolumn{1}{c}{ Bacterial strains }} & \multicolumn{5}{c}{ Compound concentration $(\mu \mathrm{g} / \mathrm{mL})$} \\
\cline { 2 - 7 } & Levofloxacin & $\begin{array}{c}\text { Tamoxifen } \\
\text { citrate }\end{array}$ & \multicolumn{2}{c}{ Compound 2 } \\
\cline { 2 - 7 } & MIC & MBC & MIC & MBC & MIC & MBC \\
\hline Listeria monocytogenes ATCC 7644 & 6.25 & $>100$ & 12.5 & 25 & 6.25 & 12.5 \\
\hline Staphylococcus aureus ATCC 6538 & 12.5 & 25 & 12.5 & 25 & 6.25 & 12.5 \\
\hline Escherichia coli ATCC 10536 & $<0.7$ & $<0.7$ & $>100$ & $>100$ & 100 & $>100$ \\
\hline Escherichia coli K12 ATCC 23716 & $<0.7$ & $<0.7$ & $>100$ & $>100$ & 25 & 50 \\
\hline
\end{tabular}

415

416 


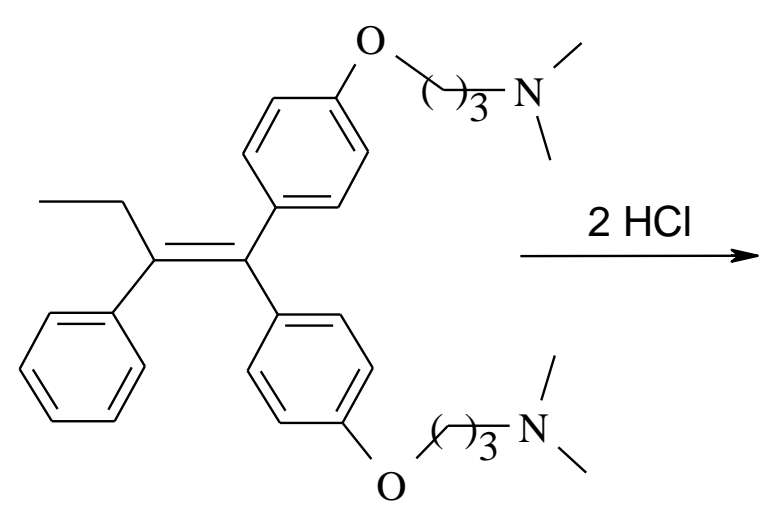

1

1,1-Bis[4-(3-dimethylaminopropoxy)phenyl] -2-phenyl-but-1-ene

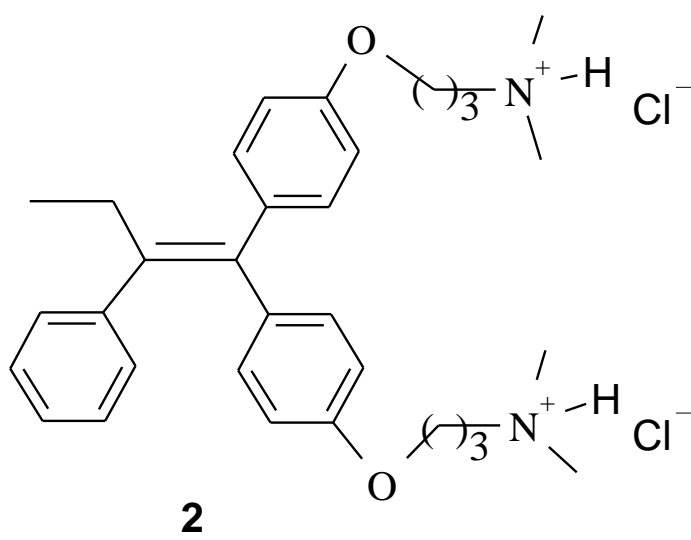

1,1-Bis[4-(3-dimethylaminopropoxy)phenyl] -2-phenyl-but-1-ene dihydrochloride

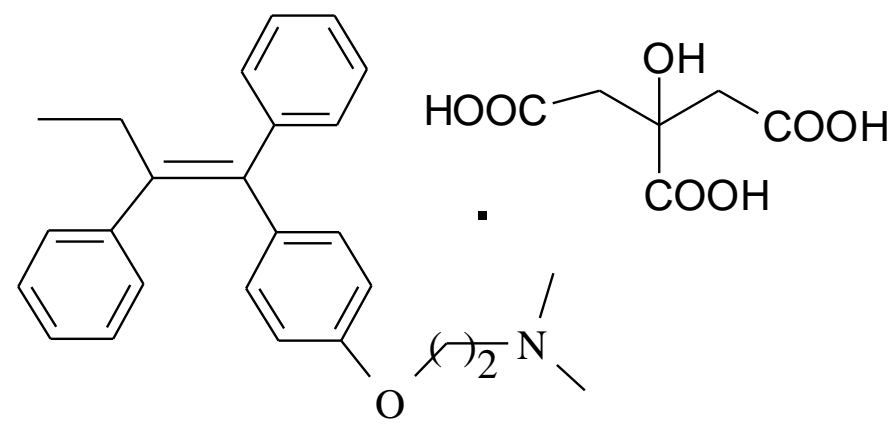

Tamoxifen citrate

Figure 1

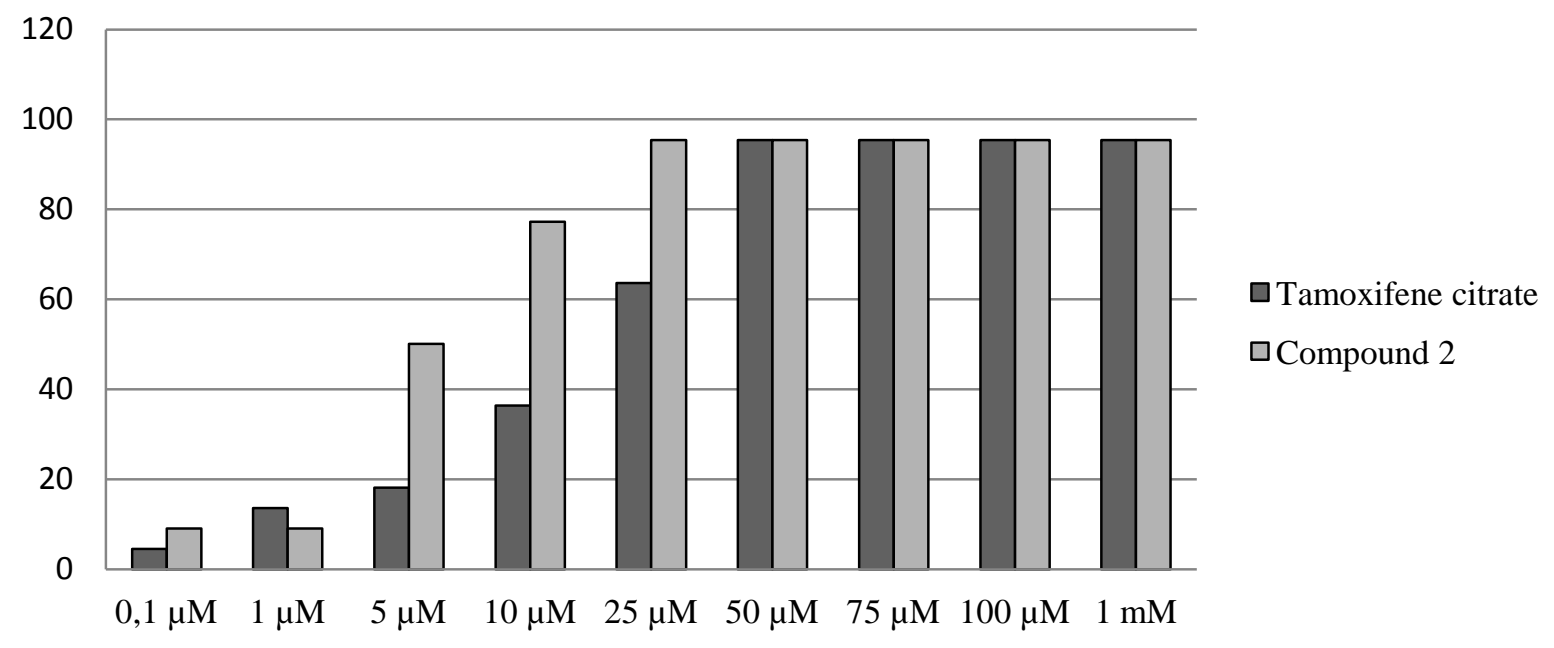




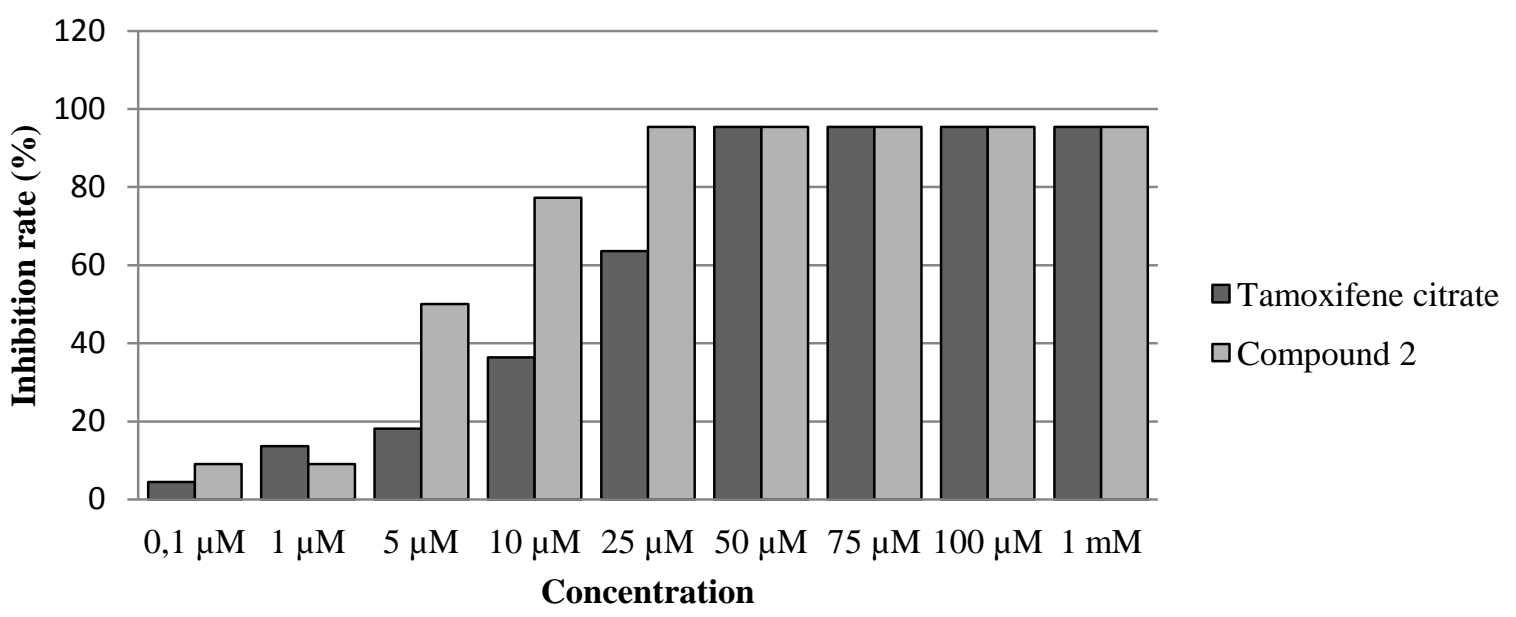

423

424 Figure 2 
A

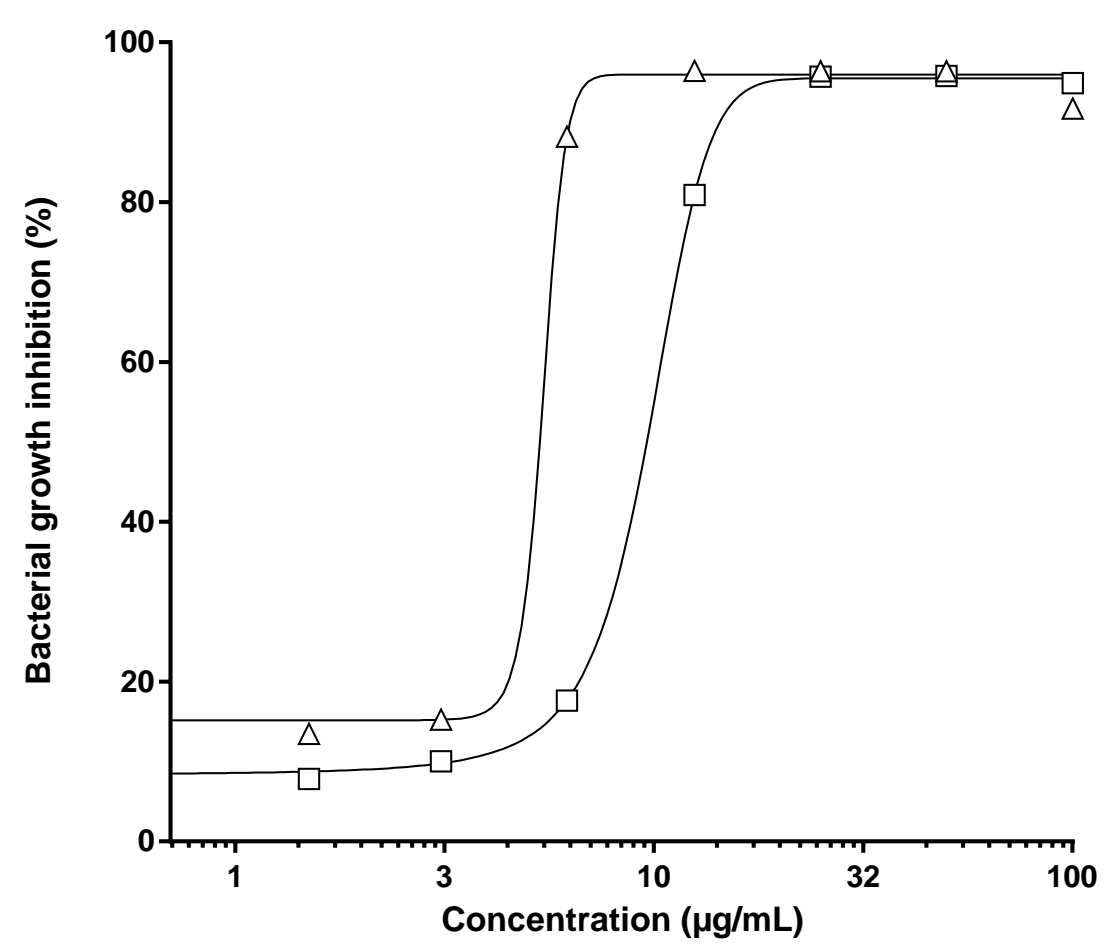

B

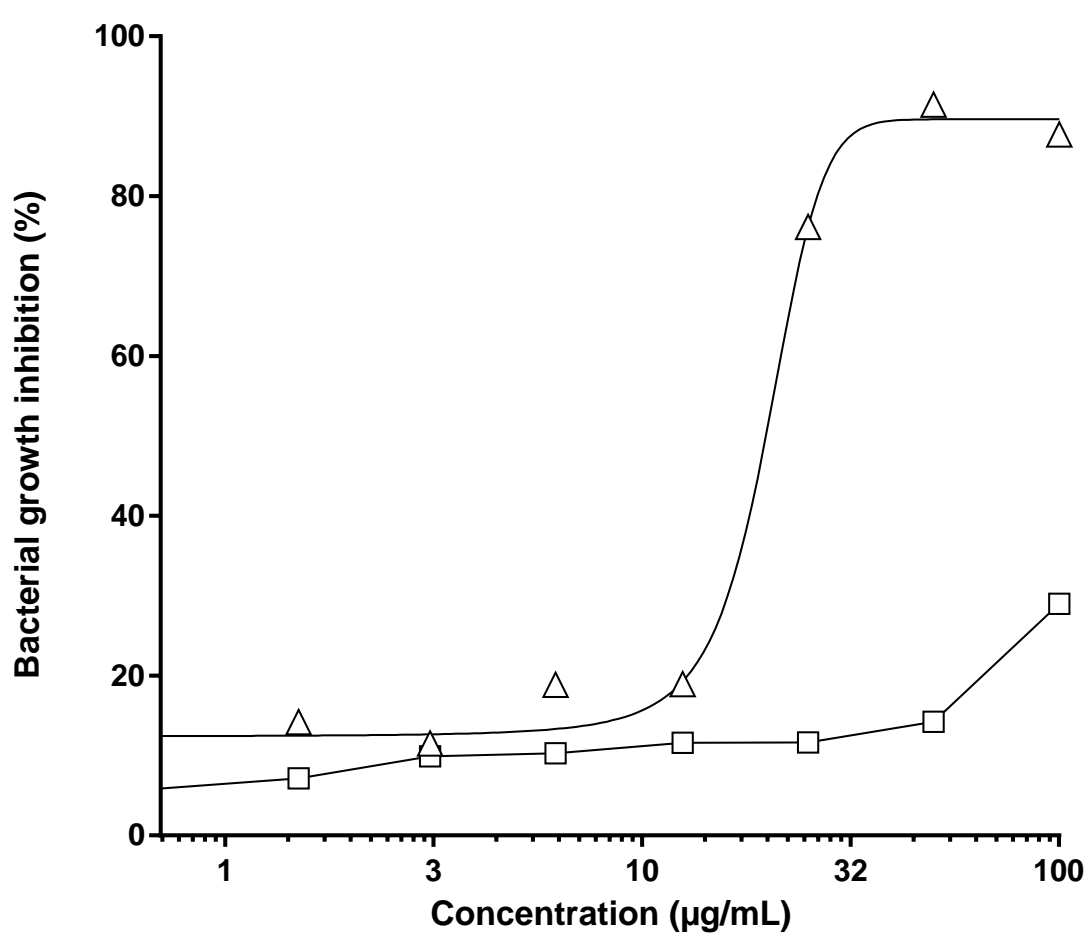

Figure 3 
A

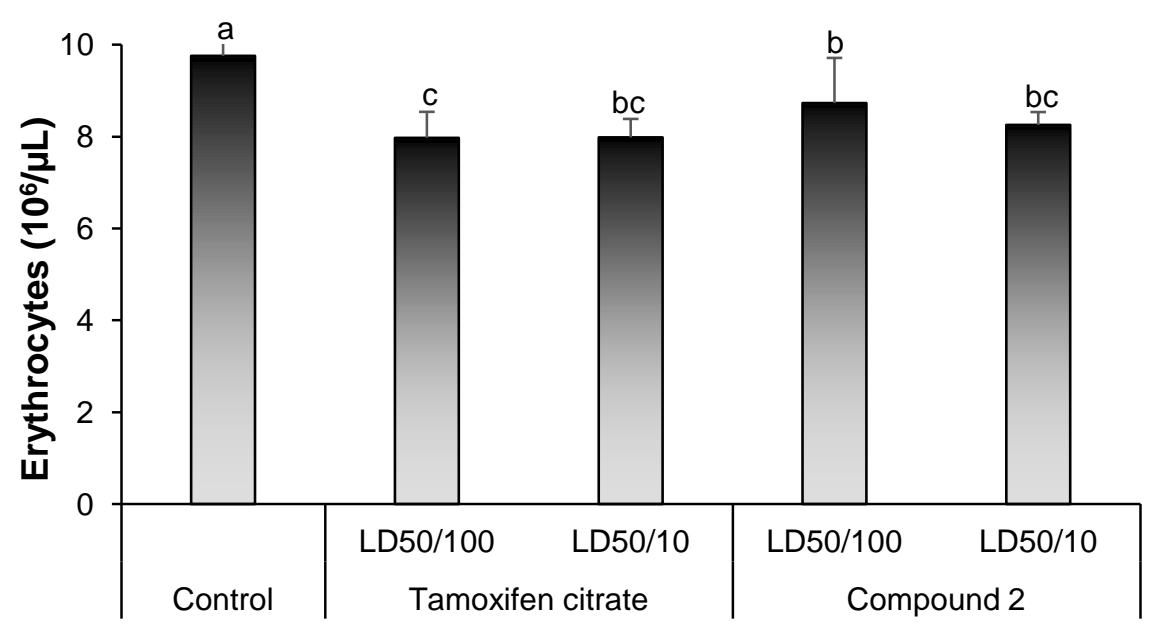

C

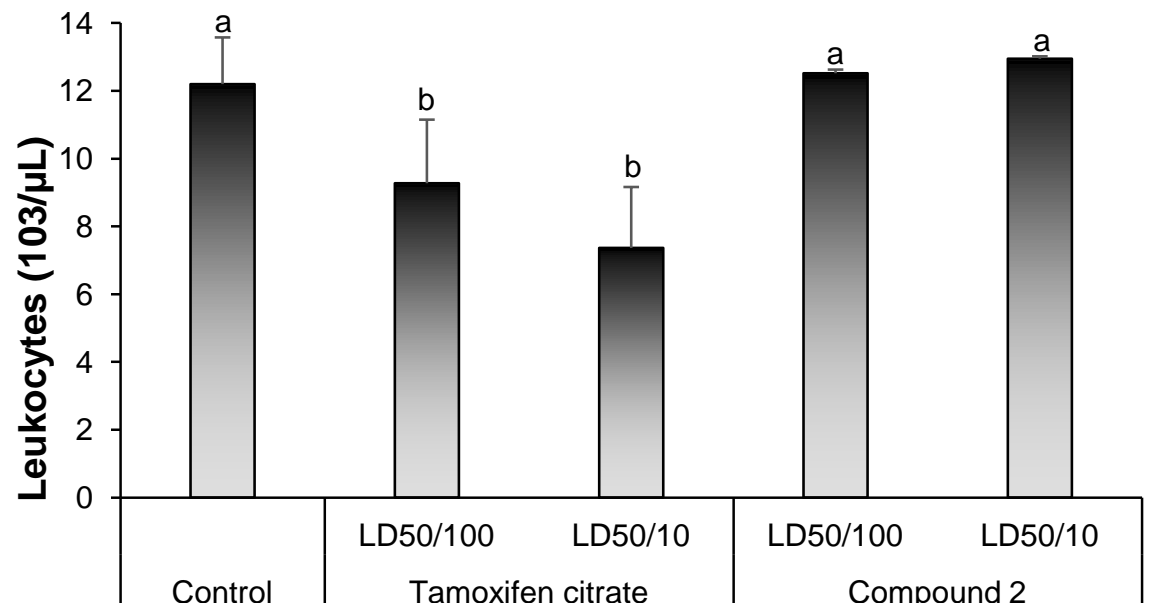

B

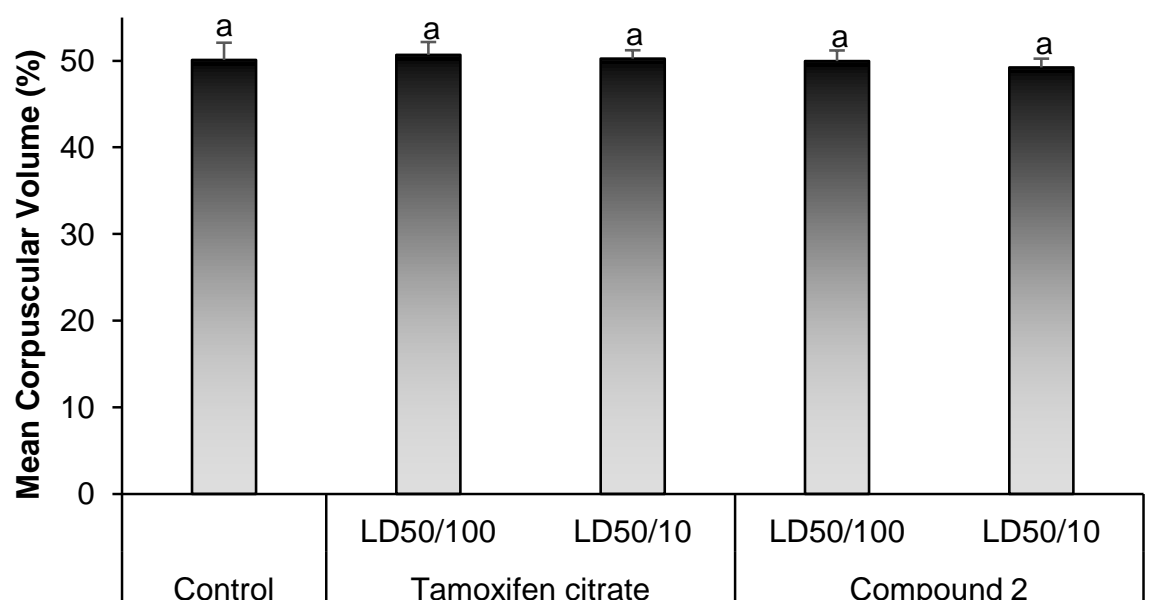

D

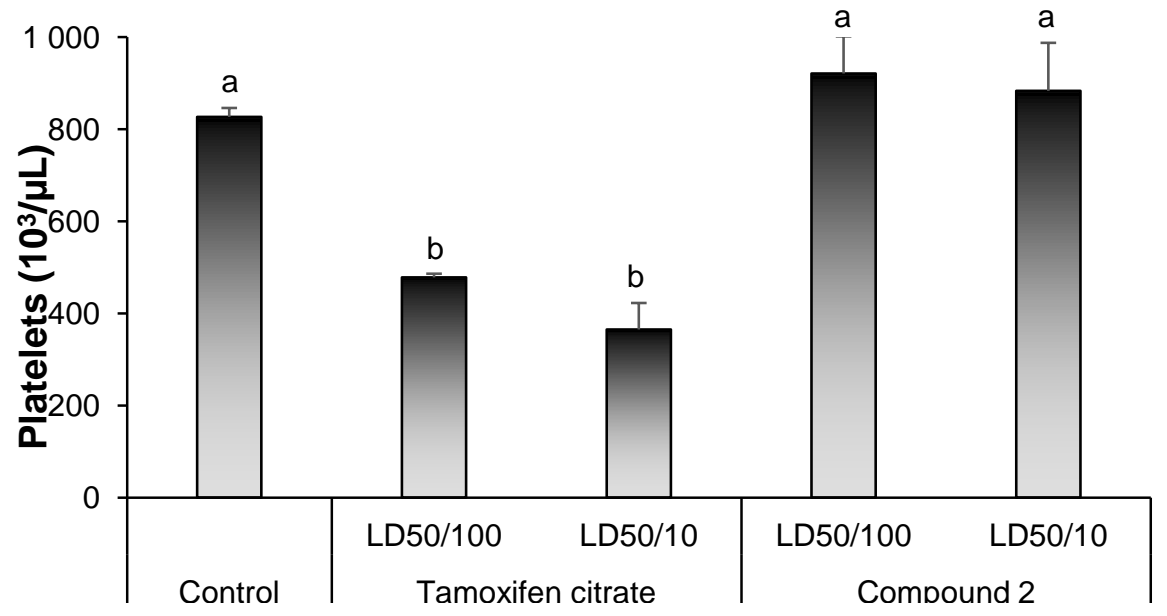

Figure4 
A

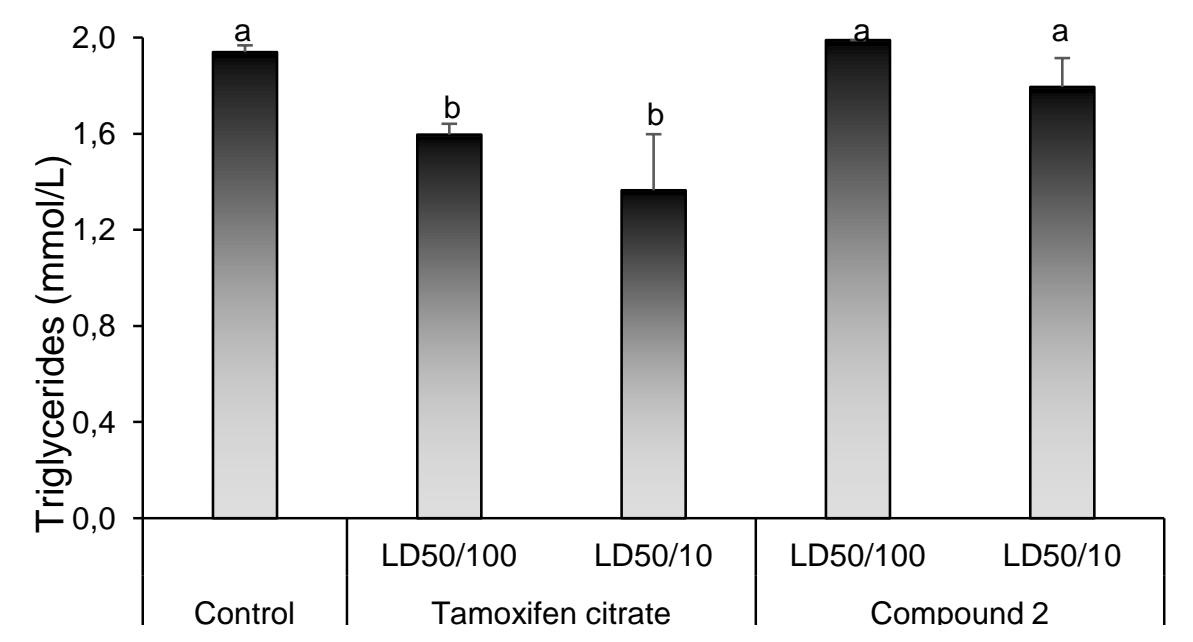

C

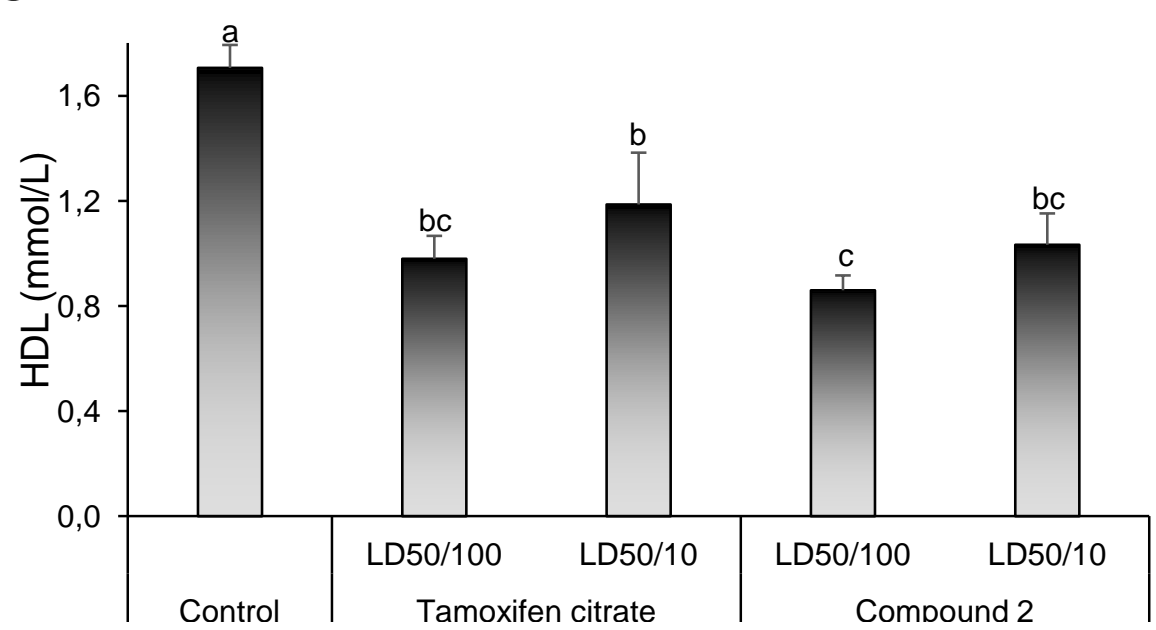

B

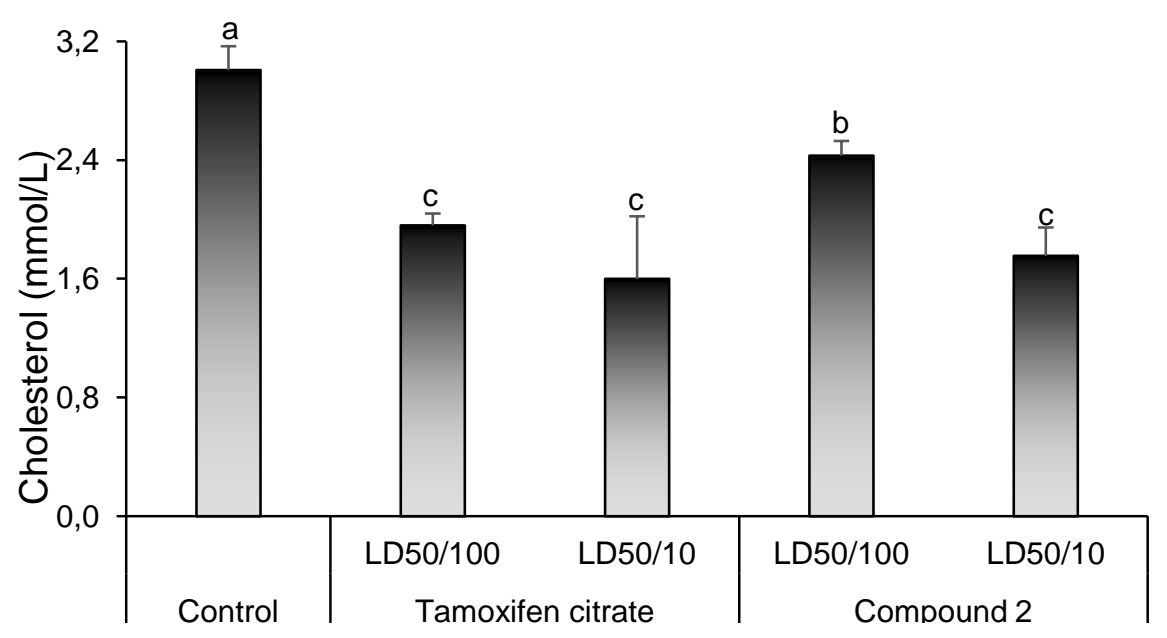

D

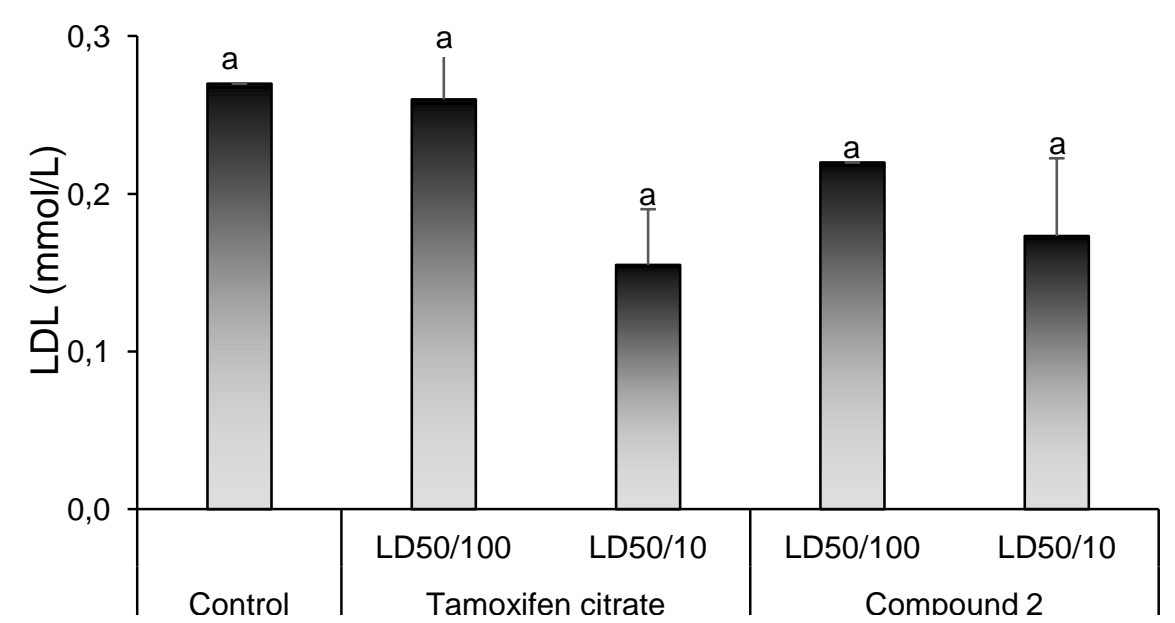

Figure 5 